UDK 630*38:625.711.84(497.6 Trnovo)

\title{
THE ANALYSIS OF THE FOREST TRUCK ROADS IN AIM OF PLANNED OPENING THE FORESTS IN THE MU ,GORNJA RAKITNICA“, FMR „TRNOVSKO“
}

\author{
Analiza šumskih kamionskih puteva u cilju planskog otvaranja šuma na \\ području GJ „Gornja Rakitnica”, ŠGP „Trnovsko” \\ Dževada Sokolović ${ }^{1}$, Nail Halimić ${ }^{2}$, Safet Gurda ${ }^{1}$, Muhamed Bajrić ${ }^{1}$, Velid \\ Halilović ${ }^{1}$, Jelena Knežević ${ }^{1}$, Adnan Hodžić ${ }^{3}$
}

\begin{abstract}
The forest truck roads, as one of the essential conditions for implementation of the planned biotechnical measures in the management unit, have to have an adequate quantity and quality. The aim of this research is determination of quantity and quality of the forest truck roads in the Management Unit (MU) „Gornja Rakitnica“, Forest Management Region (FMR) „Trnovsko“. The accessibility through wider categories of forest and total accessibility for MU have been calculated by the analysis of quantities indicators of the primary network of roads. The accessibility of the most important category of forests, from economy aspect, has been calculated - the forests with natural renewal. This accessibility amounts $12,7 \mathrm{~m} / \mathrm{ha}$. By the comparison of the values with the recommended minimum and optimum accessibility, it has been calculated that it is necessary to construct new forest truck roads. The data about quality have been obtained on the basis of terrain measurements in two forest truck roads „Rakitnica-Zućina vrela“ and „Pijevac - Borovac“. By the analysis of qualitative indicators in the analyzed roads it has been concluded that the network of forest truck roads in the MU "Gornja Rakitnica“ is passable i.e. it enables implementation of planned activities from all forest fields. The technical elements of the measured roads enable the values defined by technical regulations. The constructive elements: carriageway condition, slope cuttings, ditches and objects on the road are not in an adequate condition. If the adequate recovery works are not undertaken it could cause progressive deterioration of roads, which could influence functionality of roads transport of timber, access to compartments, etc... For the improvement of the condition of forest truck roads, the measures of recovery have been designed and the calculation of total and average costs has been carried out.
\end{abstract}

\footnotetext{
${ }^{1}$ University of Sarajevo, Faculty of Forestry

2 Public Enterprise "Sarajevo šume", Sarajevo

${ }^{3}$ Public Enterprise „Hercegbosanske šume“, Kupres
} 
Key words: accessibility, technical elements of forest truck roads, maintenance of forest truck roads

\section{INTRODUCTION - Uvod}

Modern and economical management of forests, one of the essential objectives of the forest enterprise, is not possible to be achieved without an adequate network of forest roads network (PENTEK ET AL 2003, KRČ ET AL 2013, DANiLOVIĆ ET AL 2014). Taking into account that forest truck roads are permanent forest roads they are constructed where it is justified regarding traffic load and terrain slope (PENTEK ET AL 2014). The costs of forest truck roads building are pretty high. According to SOKOLOVIĆ ET AL (2011) the costs of the building of the forest truck roads in the area of Federation of Bosnia and Herzegovina amount 25.564,59 €/km while in the Republic of Srpska the costs of the building of the forest truck roads amount $35.790,43 € / \mathrm{km}$ (POTOČNIK ET AL 2012).

Due to fact that forest truck roads are exposed to continuous climate changes and traffic load impacts it causes damages it is necessary to undertake the adequate maintenance works. The maintenance can be defined as set of works which should be occasionally carried out on the roads, auxiliary objects (ditches, culverts and cut slopes) and artificial objects (bridges, supporting walls etc.) due to provision of security of users and saving road value.

Generally, it could be said that if the more time, expertize and money have been invested in planning and construction of forest roads the maintenance costs would be lower. There are three main groups of causes for degradation of forest roads (РОтОС̌NiK, 1992): consequence of planning and construction of forest roads, consequence of inadequate usage of forest roads and consequence of natural forces.

According to Potočnik (1992), Pičman (2007) and PENTEK (2012), regarding frequency of specific works, i.e. time period of works performing, two main groups of maintenance exists: regular and investment.

The regular maintenance consists of continuous supervision and control in order to determine eventual malfunctions and damages of the road. The clearance of ditches, carriageways, berms, culverts, grass mowing and maintenance of planted vegetation, etc. are consisting activities of regular maintenance. For this kind of maintenance works the costs are the most often $2-4 \%$ of their construction costs according to РОтоČNiK et al (2012). The result of untimely or inadequate maintenance impacts on difficulties in usage, accelerated decreasing of road value and funds invested in its construction and it could be the reason for occurrence of the significant environmental (ecological) problems. The investment maintenance encompasses the carriageway renewal in the areas where the bigger potholes cover $15 \%$ of total carriageway area, or in the areas where deformation and deterioration of carriageway construction have been occurred. The strengthening of carriageway construction by making new layer, replacement of damaged supporting walls and repairs of bridges are consisting parts of investment maintenance. 
According to The Law on forestry (2002) forest truck roads should to be constructed and maintained by forest enterprises. The most significant change in The Law which has been related to forest truck roads for the last twenty years in Federation of $\mathrm{B} \& \mathrm{H}$ is that the transport of wooden assortment has been undertaken by private transporters.

In accordance with The Law private transporters have the authorization to use forest truck roads for the free, without payment of any fees. The number of users of forest truck roads have been growing day by day as for example for the transport of materials from forest stone - pits, woodland private owners, for the tourism needs, local inhabitants, etc. (HRIBERNiK, РотоČNik 2013). The more numerous users in continuity have imposed justification for the law provision of including the all users of forest truck roads in co-financing the costs related to forest truck roads.

Taking into account the fact that significant length of the forest truck roads in Bosnia and Herzegovina had been constructed approximately the half century ago and questionable quality of the new construction, the assessment of quality status of the forest truck roads constructed has been imposed as the inevitable (KOZAR, 2009). The additional reason for the need of analyzing of quality status of forest truck roads is also the slow dynamics of new construction of forest truck roads which amounts 41,6 $\mathrm{km} /$ year in Federation of B\&H according SOKOLOVić ET AL 2013. The task of the existing network of forest truck roads is the undertaking of the complete traffic load which could cause the faster deterioration of the forest truck roads. The quantitative and qualitative analysis of forest truck roads is the basis for deriving conclusions whether the existing network of forest truck roads is in the adequate condition which enables performing of the planned activities of forest enterprises.

The aim of this article is the determination of quantitative and qualitative elements of the network of forest truck roads in Management Unit (MU) "Gornja Rakitnica", Forest Management Region (FMR) "Trnovsko". The analysis will be carried out by performing of the following tasks:

- recording and analysis of the quantitative elements of the primary network,

- recording and analysis of the qualitative elements of the primary network,

- recording and analysis of the condition of the forest truck roads and

- planning of the necessary measures for improving the quality to an adequate level.

\section{MATERIAL AND METHODS OF RESEARCH - Materijal i metode istraživanja}

The length and spatial allocation of the primary network of roads at the analyzed area will be obtained through recording by GPS device. The GPS has been applied for recording the points which represent the route of road. After recording at the terrain by software package Mobile Mapper the data will be converted into computer. By means of the same software, conversion of the data into SHP format suitable for WINGIS software will be carried out. The processing of the gathered data will be done by WINGIS software. 
The forest roads on which the samples for assessment of qualitative data will be set up are the forest truck roads "Rakitnica-Zućina vrela" and "Pijevac-Borovac". The route length of these roads amount $13.818,73 \mathrm{~m}$ which makes $17,38 \%$ of share in the total length of the primary network of roads in the MU "Gornja Rakitnica".

The data about condition of constructive elements at the forest truck road have been collected on the basis of samples. The type of sample which has been used is random sample in the shape of the stationary points on which the elementary areas have been extracted. The distance amongst the stationary points has amounted $20 \mathrm{~m}$. The elementary areas have been rectangle shape with longer side $20 \mathrm{~m}$. The shorter rectangle side has been determined by the width of the carriageway. The width of carriageway amounts $4 \mathrm{~m}$ at the analyzed forest truck roads at straight parts. At the elementary areas the data about the condition of the constructive elements of road have been gathered as follows: carriageway condition, condition of the slopes, condition of the ditchess and condition of the culverts according to the methodology SOKOLOVić (2014).

The determination of categorization of the forest truck roads, analysis of the condition of forest truck roads and accessibility according to categories of forest truck roads in the researched area will be done after collection of the data at the terrain and their analysis and presentation by WINGIS software package. The Microsoft Excel 2007 software has been used for the processing of the collected data.

For the needs of this article MU "Gornja Rakitnica" has been selected. This MU belongs to FMR "Trnovsko". This area is located at Southeast from Sarajevo at the distance of approximately $30 \mathrm{~km}$.

\section{RESULTS - Rezultati istraživanja}

\section{The analysis of quantitative indicators of the primary network - Analiza kvantitativnih pokazatelja primarne mreže}

The accessibility of high forest natural renewal has been calculated by recording and measuring of the total length of primary network of forest roads in MU "Gornja Rakitnica". This accessibility amounts $12,7 \mathrm{~m} / \mathrm{ha}$. The average accessibility of MU amounts $11,5 \mathrm{~m} / \mathrm{ha}$. The construction of new forest truck roads is the unique measure which results with increasing of accessibility level. The minimum accessibility is $15 \mathrm{~m} /$ ha while optimum accessibility is $25 \mathrm{~m} /$ ha taking into account the fact that area belongs to mountain terrains category. The length of existing network and calculation of length of roads which should be constructed for achievement of minimum and optimum accessibility have been given. It could be concluded that missing length of roads for the achievement of minimum and optimum accessibility amounts $20,7 \mathrm{~km}$ and $84,2 \mathrm{~km}$ (Table 1). The number of arrangement periods and years when the quoted accessibilities would be achieved, have been calculated taking into account the presumption that $3 \mathrm{~km}$ of the new roads should be constructed during the course of one arrangement period. The numbers are as following: 
- 7 arrangement periods or more precisely 69 years for the achievement of the accessibility of $15 \mathrm{~m} / \mathrm{ha}$,

- 28 arrangement periods for the achievement of the accessibility of $25 \mathrm{~m} / \mathrm{ha}$.

Taking into consideration the average costs for $1 \mathrm{~km}$ of constructed road (SOKOLOVIĆ ET AL 2013), it should be invested $529.187 €$ for the achievement of the accessibility of $15 \mathrm{~m} / \mathrm{ha}$ in the MU "Gornja Rakitnica" or 75.598,14 $€$ for one arrangement period with dynamics of the construction of $3 \mathrm{~km} /$ arrangement period. For the achievement of accessibility of $25 \mathrm{~m} / \mathrm{ha}$ it should be invested $2.152 .538 €$ or $76.876,36 €$ for the one arrangement period.

Table 1. The illustration of the length roads which should be constructed for achievement of the minimum and optimum accessibility

Tabela 1. Prikaz dužine puteva potrebne za postizanje minimalne i optimalne otvorenosti

\begin{tabular}{|l|c|}
\hline & $\begin{array}{c}\text { The length of forest truck } \\
\text { roads, } \mathrm{km}\end{array}$ \\
\hline The existing length of the roads & 74,5 \\
\hline Minimum length of roads & 95,2 \\
\hline Optimum length of roads & 158,7 \\
\hline $\begin{array}{l}\text { The length of roads which should be constructed for achievement } \\
\text { of minimum accessibility }\end{array}$ & 20,7 \\
\hline $\begin{array}{l}\text { The length of roads which should be constructed for achievement } \\
\text { of optimum accessibility }\end{array}$ & 84,2 \\
\hline
\end{tabular}

The traffic load of forest truck roads - Saobraćajno opterećenje na šumskim kamionskim putevima

One of the most important elements which impacts on frequency and quality of the maintenance of the forest truck roads is the traffic load. Due to the fact that forest truck roads have primarily been constructed for the transport of forest wooden assortments, the timber weights which are transported mostly loads the road. The data about traffic load have been derived through quantity of timber which has been cut and transported on the basis of planned scope of cuttings and harvesting volume (KoLJić, 2010).

The harvesting volume of one compartment (measuring with $\mathrm{m}^{3}$ ) in combination with the ratio of kinds of trees and weight (measuring unit $\mathrm{kg} / \mathrm{m}^{3}$ ) for existing kinds of trees in the harvesting volume give the value of the timber weight which should be cut from the compartment in the specific year. The weight is the load amount for the part of road or the complete road from the place of timber landings to the exit to public road. It could be concluded that forest truck roads "Rakitnica-Zućina vrela" belongs to category of roads for the traffic of medium load, because the highest load in the period of the transport of forest wooden products amounts $663 \mathrm{t} /$ day, while forest truck road "Pijevac-Borovac" belongs to category of roads for the traffic of low loads with the average daily load in the period of the transport of forest wooden products under $500 \mathrm{t} /$ day (Table 2). 
Table 2. The amount of traffic load of the analyzed roads in the time period from 2004. to 2012.

Tabela 2. Veličina saobraćajnog opterećenja analiziranih puteva u periodu od 2004. do 2012.

\begin{tabular}{|c|c|c|c|c|}
\hline \multirow{2}{*}{ Year } & \multicolumn{2}{|c|}{$\begin{array}{l}\text { The total traffic of forest } \\
\text { truck road ( } \mathrm{t} / \text { year })\end{array}$} & \multicolumn{2}{|c|}{$\begin{array}{l}\text { The average traffic load in the period of the } \\
\text { wooden assortments transport ( } \mathrm{t} / \text { day) }\end{array}$} \\
\hline & $\begin{array}{l}\text { Rakitnica - } \\
\text { Zućina vrela }\end{array}$ & $\begin{array}{l}\text { Pijevac - } \\
\text { Borovac }\end{array}$ & Rakitnica - Zućina vrela & Pijevac - Borovac \\
\hline 2004 & & 632,00 & & 42,00 \\
\hline 2005 & & 5640,00 & & 376,00 \\
\hline 2006 & 9942,00 & & 663,00 & \\
\hline 2007 & & 3558,00 & & 237,00 \\
\hline 2008 & & 1958,00 & & 131,00 \\
\hline 2009 & 7533,00 & & 502,00 & \\
\hline 2010 & 3755,00 & & 250,00 & \\
\hline 2011 & 3846,00 & & 256,00 & \\
\hline 2012 & 8390,00 & & 559,00 & \\
\hline $\begin{array}{l}\text { Maximum } \\
\text { load }\end{array}$ & 9942,00 & 5640,00 & 662,80 & 376,00 \\
\hline $\begin{array}{c}\text { Average } \\
\text { load }\end{array}$ & 6693,20 & 2947,00 & 446,21 & 196,47 \\
\hline Total load & 33466.00 & 11788,00 & 2231,07 & 785,87 \\
\hline
\end{tabular}

The recording of qualitative elements of forest truck roads - Snimanje kvalitativnih elemenata na šumskim kamionskim putevima

The recording of qualitative elements of forest truck roads encompasses the recording of condition of constructive elements of forest truck roads. The analysis of existing condition of forest truck roads and determination of average costs of recovery of recorded forest truck roads have been done on the basis of the data from the terrain. On the basis of these costs it is possible to carry out projection of recovery costs of all forest truck roads in the MU.

\section{The carriageway condition - Stanje kolovoza}

On the basis of gathered data from the terrain the calculation of data has been done. It could be concluded that the half of length on the both analyzed forest truck roads has been damaged, while the half of the length on the both analyzed forest truck roads has not be damaged (Table 3). Within damaged road sections of the analyzed forest truck roads the most frequent damage is the potholes type. These road sections have been shown in the (Figure 1) and will be subject of recovery. 
The analysis of the forest truck roads in aim of planned opening the forests in the MU „, Gornja Rakitnica“, FMR ,Trnovsko“

Table 3. The carriageway layer condition of forest truck roads

Tabela 3. Stanje kolovoza na šumskim kamionskim putevima

\begin{tabular}{|c|c|c|c|c|}
\hline \multicolumn{5}{|c|}{ The forest truck road "Rakitnica-Zućina vrela" } \\
\hline Carriageway condition & Good & The potholes & The major damages & $\begin{array}{l}\text { Damages } \\
\text { in total }\end{array}$ \\
\hline $\begin{array}{l}\text { The number of road } \\
\text { sections }\end{array}$ & 11 & 8 & 4 & 12 \\
\hline Area $\left(\mathrm{m}^{2}\right)$ & $9.262,00$ & $6.736,00$ & $3.368,00$ & \\
\hline $\begin{array}{l}\text { The relative share in the } \\
\text { total area of the road }(\%)\end{array}$ & 48,00 & 35,00 & 17,00 & 52,00 \\
\hline \multicolumn{5}{|c|}{ The forest truck road „Pijevac - Borovac“ } \\
\hline $\begin{array}{l}\text { The number of road } \\
\text { sections }\end{array}$ & 20 & 11 & 13 & 24 \\
\hline Area $\left(\mathrm{m}^{2}\right)$ & $558.360,00$ & $102.366,00$ & $362.934,00$ & \\
\hline $\begin{array}{l}\text { The relative share in the } \\
\text { total area of the road }(\%)\end{array}$ & 45,00 & 25,00 & 29 & 54,00 \\
\hline
\end{tabular}
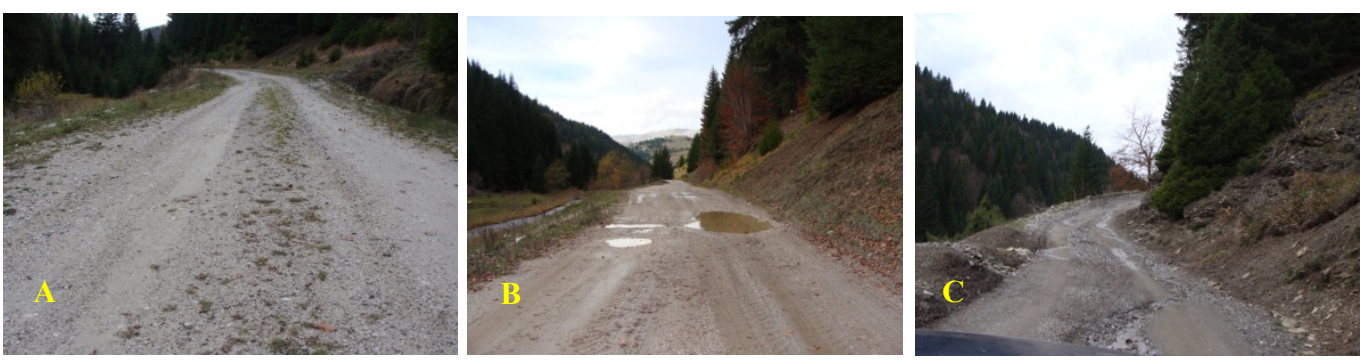

Figure 1. A - The good quality carriageway layer, B - The potholes, C - Bad carriageway layer (photo org. Halimić, 2012.)

Slika 1. A - Dobar kolovozni sloj, B - Udarne rupe i C-Odnošenje kolovoznog sloja (foto org. Halimić, 2012.)

\section{The condition of ditches - Stanje odvodnih kanala}

The ditches are used for collecting of surface waters and their channelled draining to culverts or load sections where they are drained by natural draining. The shape and dimension of ditches at the analyzed forest truck roads are $3 \times 0,5 \mathrm{~m}$ with and $0,5 \mathrm{~m}$ depth. 
Table 4. The condition of ditches of the forest truck roads Tabela 4. Stanje odvodnih kanala šumskih kamionskih puteva

\begin{tabular}{|l|c|c|c|c|}
\hline \multicolumn{5}{|c|}{ The forest truck road "Rakitnica - Zućina vrela" } \\
\hline The condition of ditches & Good & $\begin{array}{c}\text { Cleansing } \\
\text { needed }\end{array}$ & $\begin{array}{c}\text { Digging } \\
\text { needed }\end{array}$ & Total \\
\hline The number of road sections & 7,00 & 3,00 & 13,00 & 23,00 \\
\hline The length of road (m) & $1.400,00$ & 600,00 & $2.600,00$ & $4.600,00$ \\
\hline $\begin{array}{l}\text { The relative share in total length of } \\
\text { the road (\%) }\end{array}$ & 30,00 & 13,00 & 47,00 & 100,00 \\
\hline \multicolumn{7}{|c|}{ The forest truck road "Pijevac - Borovac" } & 29 & 47 \\
\hline The number of road sections & 12 & 6 & $5.800,00$ & $9.400,00$ \\
\hline The length of road (m) & $2.400,00$ & $1.200,00$ & 62,00 & 100,00 \\
\hline $\begin{array}{l}\text { The relative share in total length of } \\
\text { the road (\%) }\end{array}$ & 26,00 & 12,00 & & \\
\hline
\end{tabular}
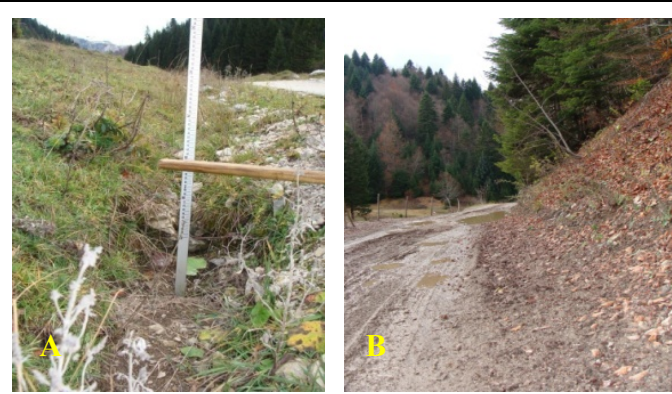

Figure 2. A- The cleansing needed, B- The digging of ditches needed (photo org. Halimić, 2012)

Slika 2. A-Potrebno čišćenje kanala, B - Potreban iskop kanala (foto org. Halimić, 2012)

In the forest truck road "Rakitnica-Zućina vrela", the ditches have not been registered on the $47 \%$ of the length so the digging is necessary. In the road leg of approximately $600 \mathrm{~m}$ it is necessary to carry out digging of the ditches. In the forest truck road "Pijevac-Borovac" it is necessary to carry out cleansing on the length of approximately $1.200 \mathrm{~m}$ and digging is necessary on the length of approximately 5.800 $\mathrm{m}$ (Table 4, Figure 2).

\section{The condition of cut slopes and embankments - Stanje škarpi}

In the both of two analyzed forest truck roads, less or more eroded cut slopes and embankments have been registered (Table 5). The significant erosion of slopes is consequence of gravitation water activity (gravitation water is abundant in this area) and climate circumstances (mountain climate) and type of geologic foundation and 
soil. The erosion of slopes in notch causes plugging of drainers with materials amongst other consequences.

By the plugging of drainers, gravitation water has been moving along the road surface which causes deterioration of carriageway surface layer. It is inevitable to recover the cut slopes and embankments with decreased stability and evident tracks of erosion by civil works to prevent manifesting of these and other negative consequences (mobility and safety of traffic) caused by cut slopes and embankments.

Table 5. The condition of cut slopes and embankments

Tabela 5. Stanje škarpi

\begin{tabular}{|l|c|c|c|c|}
\hline \multicolumn{5}{|c|}{ The forest truck road "Rakitnica-Zućina vrela" } \\
\hline $\begin{array}{l}\text { The condition of cut slopes } \\
\text { and embankments }\end{array}$ & Good & $\begin{array}{c}\text { Trimming bushes } \\
\text { needed }\end{array}$ & $\begin{array}{c}\text { Earthworks } \\
\text { needed }\end{array}$ & Total \\
\hline Number of road sections & 10,00 & - & 13,00 & 23,00 \\
\hline The length of road (m) & $2.000,00$ & - & $2.600,00$ & $4.600,00$ \\
\hline $\begin{array}{l}\text { The relative share in total } \\
\text { length of the road (\%) }\end{array}$ & 44,00 & - & 56,00 & 100,00 \\
\hline \multicolumn{7}{|c|}{ The forest truck road "Pijevac - Borovac" } \\
\hline Number of road sections & 34 & - & 13 & 47 \\
\hline The length of road (m) & $4.800,00$ & - & $2.600,00$ & $9.400,00$ \\
\hline $\begin{array}{l}\text { The relative share in total } \\
\text { length of the road (\%) }\end{array}$ & 72,00 & - & 28,00 & 100,00 \\
\hline
\end{tabular}

\section{The condition of culverts - Stanje propusta}

In the forest truck road seven concrete culverts with diameter of $60 \mathrm{~cm}$ have been registered (Table 6).

Table 6. The condition of culverts in the forest truck roads

Tabela 6. Stanje propusta na šumskim kamionskim putevima

\begin{tabular}{|l|c|c|c|c|}
\hline \multicolumn{7}{|c|}{ The forest truck road "Rakitnica-Zućina vrela" } \\
\hline The culvert condition & Good & Cleansing needed & Construction needed & Total \\
\hline Number of culverts & 2,00 & 2,00 & 3,00 & 7,00 \\
\hline \multicolumn{7}{|c|}{ The forest truck road "Pijevac-Borovac" } \\
\hline Number of culverts & 7,00 & 9,00 & 2,00 & 18,00 \\
\hline
\end{tabular}

It could be calculated that only 9 (nine) culverts perform their function in the analyzed forest truck roads. It is inevitable to carry out recovery by civil works on the other culverts to make them functional. 


\section{DISCUSSION - Diskusija}

By terrain recordings and analysis of the condition of the analyzed forest truck roads it has been determined that constructive elements and objects are not in optimum condition. On the basis of the analysis of condition of constructive elements it has been determined that slope cuts had been eroded, that drainers don't exist in the more than half of length of both roads and significant number of culverts don't perform their function at all. The minor damages of carriageway of the holes type exist in the roads. These damages do not only decrease speed of timber transport from the forest but they can cause the more progressive deterioration of the forest truck road. In that context, it is necessary to carry out recovery of both of the analyzed forest truck roads, if it is wanted to prevent further deterioration of the road, increase speed and economy of the timber (wood transport from the forest to higher level, and if it is wanted to prevent ecological damages, development of torrent and disturbance of the regime of waters.

The designed measures of maintenance, the scope of works of working devices and total direct costs of the works per kind of the works for both of analyzed truck roads have been shown (Tables 7 and 8 ).

In the (Figure 3) the road sections where the designed works would be carried out have been shown. The total direct costs of the works according to kind of recovery works have been calculated on the basis of "Internal norms" for the "Civil-mechanical works" of WO (Working organization) "Sipad-Jahorina"1991. year and The price list of services of civil mechanization and vehicles Public Enterprise "Unsko-Sanske šume", 2012. The direct costs of the recovery have been shown in the Table 8 .

It could be concluded that average direct recovery costs of $1 \mathrm{~km}$ of the forest truck road "Pijevac-Borovac" amount 6.037,33 €. In the structure of costs major share belongs to carriageway recovery ( $72 \%$ out of the total costs).

It accordance with the research SOKOLOVić ET AL (2014) and HRIBERNIK (2004), the average costs of recovery of the forest truck roads in the area amount 7.538,5846 $€ / \mathrm{km}$ and $8.576,41 € / \mathrm{km} /$ year.

The reasons for the significant varying of necessary funds for the recovery of the forest truck roads are numerous, and the most significant of them are as follows: different traffic load, different time of the latest works on the roads and different geological - pedological foundation. 
The analysis of the forest truck roads in aim of planned opening the forests in the MU „, Gornja Rakitnica“, FMR ,,Trnovsko“"

Table 7. The kind and scope of the maintenance works in the forest truck roads Tabela 7. Vrste i obim radova održavanja na šumskim kamionskim putevima

\begin{tabular}{|c|c|c|c|}
\hline \multicolumn{4}{|c|}{ Forest truck roads „Rakitnica - Zućina vrela“ } \\
\hline The kind of works & The des & ption of works & \\
\hline \multirow{5}{*}{ The carriageway recovery } & The operation & $\begin{array}{c}\text { The working } \\
\text { device }\end{array}$ & $\begin{array}{l}\text { The scope of } \\
\text { works }\end{array}$ \\
\hline & $\begin{array}{l}\text { Tightening of longitudinal } \\
\text { profile of the road surface }\end{array}$ & Grader MG145 & $2.400,00 \mathrm{~m}$ \\
\hline & $\begin{array}{l}\text { Procurement, shipping and } \\
\text { transport of materials }\end{array}$ & $\begin{array}{l}\text { Truck MAN TG - } \\
\text { A } 35.430 \text { KIPER }\end{array}$ & $960,00 \mathrm{~m}^{3}$ \\
\hline & Spreading of materials & Grader MG145 & $960,00 \mathrm{~m}^{3}$ \\
\hline & Rolling of materials & Roller DVV11 & $9.600,00 \mathrm{~m}^{2}$ \\
\hline \multirow[b]{2}{*}{ The recovery of scarps } & Cutting slope cuts & Ditcher $\mathrm{G}-1000$ & $2.600,00 \mathrm{~m}$ \\
\hline & The transport of materials & $\begin{array}{c}\text { Truck MAN TG - } \\
\text { A } 35.430 \text { KIPER }\end{array}$ & $3.900,00 \mathrm{~m}^{3}$ \\
\hline \multirow{3}{*}{ The recovery of drainers } & Cleaning of drainage ditches & \multirow[b]{2}{*}{ Grader MG145 } & $600,00 \mathrm{~m}$ \\
\hline & $\begin{array}{l}\text { Excavation of drainage } \\
\text { ditches }\end{array}$ & & $2.600,00 \mathrm{~m}$ \\
\hline & The transport of materials & $\begin{array}{l}\text { Truck MAN TG - } \\
\text { A } 35.430 \text { KIPER }\end{array}$ & $240,00 \mathrm{~m}^{3}$ \\
\hline \multirow{2}{*}{ The recovery of culvert } & Cleansing & \multirow{2}{*}{$\begin{array}{l}\text { Ditcher G - } 1000 \\
\text { and KV workers }\end{array}$} & $2,00 \mathrm{kom}$ \\
\hline & Construction & & $3,00 \mathrm{kom}$ \\
\hline \multicolumn{4}{|c|}{ Forest truck roads "Pijevac-Borovac" } \\
\hline \multirow{4}{*}{ The carriageway recovery } & $\begin{array}{l}\text { Tightening of longitudinal } \\
\text { profile of the road surface }\end{array}$ & Grader MG145 & $2.200,00 \mathrm{~m}$ \\
\hline & $\begin{array}{l}\text { Procurement, shipping and } \\
\text { transport of materials }\end{array}$ & $\begin{array}{l}\text { Truck MAN TG - } \\
\text { A } 35.430 \text { KIPER }\end{array}$ & $880,00 \mathrm{~m}^{3}$ \\
\hline & Spreading of materials & Grader MG145 & $880,00 \mathrm{~m}^{3}$ \\
\hline & Rolling of materials & Roller DVV11 & $8.800,00 \mathrm{~m}^{2}$ \\
\hline \multirow[b]{2}{*}{ The recovery of scarps } & Cutting slope cuts & Ditcher G - 1000 & $2.600,00 \mathrm{~m}$ \\
\hline & The transport of materials & $\begin{array}{l}\text { Truck MAN TG - } \\
\text { A } 35.430 \text { KIPER }\end{array}$ & $2.600,00 \mathrm{~m}^{3}$ \\
\hline \multirow{3}{*}{ The recovery of drainers } & Cleaning of drainage ditches & Ditcher $G-1000$ & $1.200,00 \mathrm{~m}$ \\
\hline & $\begin{array}{l}\text { Excavation of drainage } \\
\text { ditches }\end{array}$ & Grader MG145 & $5.800,00 \mathrm{~m}$ \\
\hline & The transport of materials & $\begin{array}{l}\text { Truck MAN TG - } \\
\text { A } 35.430 \text { KIPER }\end{array}$ & $525,00 \mathrm{~m}^{3}$ \\
\hline \multirow{2}{*}{ The recovery of culvert } & The cleansing & \multirow{2}{*}{$\begin{array}{l}\text { Ditcher G - } 1000 \\
\text { and KV workers }\end{array}$} & 9,00 kom \\
\hline & Construction & & $2,00 \mathrm{kom}$ \\
\hline
\end{tabular}


Table 8 . The direct costs of the recovery of the forest truck roads Tabela 8. Direktni troškovi sanacije šumskih kamionskih puteva

\begin{tabular}{|c|c|c|}
\hline \multicolumn{3}{|c|}{ The forest truck road „Rakitnica - Zućina vrela“ } \\
\hline The kind of works & The total costs $(€ / \mathrm{km})$ & The percentage share $(\%)$ \\
\hline The carriageway recovery & 21427,64 & 69,46 \\
\hline The recovery of scarps & 7395,31 & 23,97 \\
\hline The recovery of ditches & 287,76 & 0,93 \\
\hline The recovery of culverts & $1.738,39$ & 5,64 \\
\hline Total & $30.849,09$ & 100,00 \\
\hline Average & $6.855,36$ & \\
\hline \multicolumn{3}{|c|}{ The forest truck road "Pijevac-Borovac" } \\
\hline The carriageway recovery & $19.604,6$ & 72,16 \\
\hline The recovery of scarps & $4.930,204$ & 18,15 \\
\hline The recovery of ditches & 692,2125 & 2,55 \\
\hline The recovery of culverts & $1.942,909$ & 7,15 \\
\hline Total & $27.169,93$ & 100,00 \\
\hline Average & $6.037,76$ & \\
\hline \multicolumn{3}{|c|}{$\begin{array}{l}\text { Vrste sanacionih radova/Type of } \\
\text { recovery works } \\
\text { Rupe/Potholes } \\
\text { Kolotrazi/Ruts } \\
\text { Čišćenje kanala/Cleaning ditches } \\
\text { Iskop kanala/Excavation ditches } \\
\text { Kosine usjeka/Cutting of the slope }\end{array}$} \\
\hline ; & & $\begin{array}{lll}21 & 22 \\
21 & 22 \\
21 & 22 \\
22 & 28 \\
22 & 23\end{array}$ \\
\hline
\end{tabular}

Figure 3. The illustration of the road sections of the forest truck road "Rakitnica-Zućina vrela" according to type of recovery works

Slika 3. Prikaz dionica šumskog kamionskog puta „,Rakitnica - Zućina vrela“ prema vrstama sanacionih radova

The recovery costs of all forest truck roads of MU "Gornja Rakitnica" Proračun troškova sanacije svih ŠKP u GJ „Gornja Rakitnica“

$\mathrm{T}$ he calculation of recovery costs of all forest truck roads in the MU "Gornja Rakitnica" is related to the category of forest macadam roads. The total length of the forest macadam roads in the MU "Gornja Rakitnica" amounts 29,5 km. The interval 
assessment of the total recovery costs of the forest macadam roads in the MU"Gornja Rakitnica" has been done on the basis of the data about amount of minimum and maximum average recovery costs KM/km (SOKOLOVić ET AL., 2014) and length of the macadam roads.

On the basis of data it could be determined as follows:

- The total recovery costs of the forest macadam roads in the MU "Gornja Rakitnica" amount $190.173,512 €$ for the complete arrangement period. It is necessary $19.017,50 €$ to be invested for the recovery of forest roads at the level of MU annually,

- The real recovery costs of the forest truck roads in the MU "Gornja Rakitnica" for the period of 10 years are in the interval from approximately $133.958,47 €$ to $182.869,68 €$,

- This significant variation of the costs is consequence of complete condition of the forest truck roads. Due to this fact previously quoted could be used as the orientation data only. The real recovery costs of the forest roads in the MU "Gornja Rakitnica" are in this interval.

\section{CONCLUSIONS - Zaključci}

On the basis of the research which has been comprehensively shown in this article the following essential conclusions could be derived:

The average accessibility level in the MU "Gornja Rakitnica" area amount $11,5 \mathrm{~m} / \mathrm{ha}$. According to its comparison with recommended minimum accessibility (15 $\mathrm{m} / \mathrm{ha}$ ) and optimum accessibility $(25 \mathrm{~m} / \mathrm{ha})$, it has been calculated that it is necessary to construct new $20,7 \mathrm{~km}$ of roads and invest the additional 529.187,1 $€$. For the achieving the optimum accessibility it is necessary to carry out construction of new forest truck roads of the total length of $84,2 \mathrm{~km}$ and invest the additional 5.811.854,81 $€$.

On the examples of two forest truck roads "Rakitnica-Zućina vrela" and "Pijevac-Borovac" the condition of carriageway, cut slopes, ditches and objects on the road has been assessed. This analysis have shown that if the adequate recovery work are not carried out the progressive deterioration of these forest truck roads could occur which would cause questionable functionality (transport of forest wooden products, access to compartments, et.).

Due to improvement of the analyzed forest truck roads into an adequate condition of quality the recovery measures has been planned and the calculation of the total and average costs has been done.

The projection of recovery costs of the all forest truck roads in the area of MU "Gornja Rakitnica", which have been constructed with the carriageway of macadam system, has been carried out on the basis of the average price of recovery of the forest truck roads "Rakitnica-Zucina vrela". The fluctuation of finances needed for the construction of new and maintenance of the existing forest truck roads in the analyzed 
area indicates to the conclusions that clear plans for this field of forestry dont't exist but the works has been carried out in accordance with momentary needs. This manner of the activities has been primarily caused by the lack of adequate and sufficient data on the existing forest truck roads.

The relevant data on the existing status should be the basis for creating plans for further opening and maintenance plans. Due to afore mentioned the chronology of works needed status in the field of forest truck roads is: recording and storing data on the existing status, making plans for further opening and making maintenance plans.

\section{REFERENCES - Literatura}

DANILOVIĆ M., GAČIĆ, D. 2014: Održivo koršćenje šumskih i lovnih resursa, Glasnik Šumarskog fakulteta Beograd, pp. 25-50

HRIBERNIK B., POTOČNIK I. 2006: Sedanje stanje gozdnih cest kot rezultat preteklega gospodarenja. Zbornik gozdarstva in lesarstva 81. 83-89.

HRIBERNIK B., POTOČNIK I. 2013: Forest Opening in Multipurpose Private Forest - Case Study, Nova mehanizacija šumarstva 34, pp. 29-37

JP "Unsko-sanske šume" 2012: Cijene usluga građevinske mehanizacije i vozila, Bosanska Krupa.

KoLJić, H. 2010: Inventarizacija šumskih puteva u GJ "Šiša-Palež", Završni rad I ciklusa studija, Šumarski fakultet u Sarajevu.

KRČ, J., BEGUŠ, J. 2013: Planning Forest Opening with Forest Roads, Croatian Journal of Forest Engineering, pp. 217-228

KozAR, S., SOKOLOVIĆ, Dž., BAJRić, M. 2009: Moderne kolovozne konstrukcije na šmskim kamionskim putevima, Works of the Faculty of Forestry University of Sarajevo, pp. 27-42

PENTEK T., PIČMAN, D. 2003: Uloga šumskih prometnica pri gospodarenju šumama na kršu s posebnim osvrtom na Senjsku Dragu, Šumarski list 2003, 65-78, Zagreb

Pentek T., NeVEČerel H., PIčman D., PoršInSky T. 2007: Forest road network in the Republic of Cratia - Status and perspectives. Croation Journal of Forest Engineering, Zagreb, 28 (1) 93-106.

Pentek T., NeVeČerel H., EČImović, T., LePOglaVec, K., PAPA, I., Tomašıć, Ž. 2014: Strategijsko planiranje šumskih prometnica u Republici Hrvatskoj - raščlamba postojećeg stanja kao podloga za buduće aktivnosti, Nova mehanizacija šumarstva, pp. 63-78 Zagreb

PičmAN, D. 2007: Šumske prometnice, Sveučilišni udžbenik. Šumarski fakultet Sveučilišta u Zagrebu, str. 1-460.

POTOČNiK I., LJUBOJEVić S., PETKović V., MARČETA D. 2012: Troškovi održavanja šumskih kamionskih puteva, Glasnik Šumarskog fakulteta Univerziteta u Banjoj Luci, br. 16. str 77-89

RO „ŠiPAD JAHORINA“, 1991: Interne norme za građevinsko-mašinske radove, Sarajevo. SOKOLOVIĆ, DŽ., BAJRić, M. 2011: Studija „Šumska transportna infrastruktura“ 
Federalno Ministarstvo poljoprivrede, vodoprivrede i šumarstva. pp. 1-75. < www.fmpvs.gov.ba/texts/239 349 b.pdf, (12.02.2017.)

SOKOLOVIĆ, Dž., BAJRić, M. 2013: Š́umska prometna infrastruktura u Federaciji Bosne i Hercegovine, Nova mehanizacija šumarstva, Zagreb, pp. 39-50

SOKOLOVIĆ, Dż., BAJRIĆ, M., HALILOVIĆ, V., Musić, J. 2014: The maintenance of forest truck roads in Forest Management Regions of Sarajevo canton, Works of the Faculty of Forestry University of Sarajevo, pp. 1-14

ŠIKIĆ, D., BABIĆ, B., TOPOLNIK, D., KNEŽEVIĆ, I., BOŽIČEVIĆ, D., ŠVABE, Z., PIRIA, I., SEVER, S. 1989: Tehnički uvjeti za gospodarske ceste, Znanstveni savjet za promet JAZU, Zagreb.

ŠUMSKOGOSPODARSKA OSNOVA ZA „TRNOVSKO" ŠUMSKOGOSPODARSKO PODRUČJE. Period važnosti od 01.01.2005. do 31.12.2014. godine.

ZAKON O ŠUMAMA FBiH 2002. godina. („Službene novine FBiH“, broj: 83/09)

\section{SAŽETAK}

U radu je analizirana otvorenost gospodarske jedinice „Gornja Rakitnica” primarnom mrežom puteva s obzirom na kvantitet i kvalitet. Analiza kvantiteta primarne mreže puteva je rezultirala davanjem prosječne otvorenosti područja koja iznosi $11,5 \mathrm{~m} / \mathrm{ha}$. U cilju dostizanja minimalne otvorenosti od $15 \mathrm{~m} /$ ha potrebno je izgraditi novih $20,7 \mathrm{~km}$ puteva i investirati dodatnih $529.187 €$. Na izabranim šumskim kamionskim putevima izvršena su terenska mjerenja konstruktivnih elemenata i izvršena je procjena stanja objekata. Ustanovljeno je da prosječni troškovi sanacije šumskog kamionskog puta „Rakitnica - Zucina vrela“ iznose 6.855,36 $€ / \mathrm{km}$, a za šumski kamionski put „Pijevac Borovac" $6.037,76 € / \mathrm{km}$. Na osnovu prosječne cijene sanacije analiziranih puteva izvršena je projekcija troškova sanacije svih puteva na području GJ „Gornja Rakitnica“ koji su izvedeni sa kolovozom sistema makadam. Izračunato je da prosječni troškovi sanacije šumskih kamionskih puteva u GJ iznose 190.173,512 € za cijeli uređajni period. Godišnje bi trebalo izdvojiti 19.017,50 € za sanaciju šumskih puteva na nivou gospodarske jedinice. Ocjena kvaliteta na osnovu mjerenja i snimanja stanja na dva izabrana šumska kamionska puta zasigurno neće dati realnu sliku o postojećem stanju i mjerama koje je potrebno poduzeti za unapređenje. Ovakve analize mogu dati samo orijentacione podatke o stanju šumskih kamionskih puteva. Stvarno stanje moguće je utvrditi samo terenskim snimanjima i mjerenjima na svakom šumskom kamionskom putu. Poznavanje postojećeg stanja za sve šumske kamionske puteve je početna tačka za unapređenje u ovoj oblasti kroz izradu planova budućeg otvaranja i izradu planova održavanja.

Corresponding author: Dževada Sokolović; Faculty of Forestry University Sarajevo; Zagrebačka 20, 71000 Sarajevo, Bosna\&Herzegovina; e-mail address: dz.sokolovic@sfsa.unsa.ba 